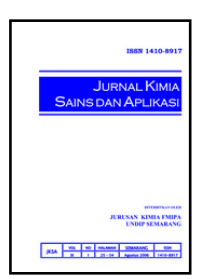

\title{
Pemanfaatan Kitosan Termodifikasi Asam Askorbat sebagai Bahan Antimikroba pada Daging Ayam Karkas Broiler
}

\author{
Titis Oktafiana Poppy ${ }^{a}$, Khabibi $^{a^{*}}$, Agustina L. N. Aminin ${ }^{a}$ \\ a Chemistry Department, Faculty of Sciences and Mathematics, Diponegoro University, Jalan Prof. Soedarto, Tembalang, Semarang \\ * Corresponding author: khabibi@live.undip.ac.id
}

\section{Article Info}

Keywords: chitosan-ascorbic acid, coating, preservative

\begin{abstract}
Chicken meat is generally a broiler carcass meat is one of the food ingredients that are widely consumed and easily decayed so it is necessary to look for alternative natural and harmless alternative preservatives such as chitosan. The aim of this study was to obtain ascorbic acid-modified chitosan used as a preservative in broiler carcass meat at cold temperature, to obtain data of curing ability between chitosan and chitosan modified ascorbic acid, and to determine the effective concentration of ascorbic acid added in chitosan modification as meat preservative chicken. The method used for preservation was the coating method. The chitosan-ascorbic acid functional group was analyzed using FTIR and to test the ability of ascorbic acid-modified chitosan as a chicken meat preservative was analyzed by Total Plate Count (TPC). The results showed that the ability of chitosan modified ascorbic acid was better than chitosan without modification. The optimum ascorbic acid concentration was at a concentration of $40 \mathrm{mmol} / \mathrm{L}$ and was able to preserve chicken meat for up to 4 weeks.
\end{abstract}

\section{Abstrak}

Daging ayam yang umumnya berupa daging ayam karkas broiler merupakan salah satu bahan pangan yang banyak dikonsumsi dan mudah busuk sehingga diperlukan bahan pengawet alternatif alami dan tidak berbahaya seperti kitosan. Penelitian ini bertujuan untuk memperoleh kitosan termodifikasi asam askorbat yang digunakan sebagai pengawet pada daging ayam karkas broiler pada suhu dingin. Dan untuk memperoleh data kemampuan pengawetan antara kitosan dan kitosan termodifikasi asam askorbat serta menentukan konsentrasi efektif asam askorbat yang ditambahkan dalam modifikasi kitosan sebagai pengawet daging ayam. Metode yang digunakan untuk dalam pengawetan adalah metode coating. Gugus fungsi kitosan-asam askorbat dianalisis menggunakan FTIR dan untuk menguji kemampuan kitosan termodifikasi asam askorbat sebagai pengawet daging ayam dilakukan analisis Angka Lempeng Total (ALT). Hasil penelitian menunjukkan bahwa kemampuan kitosan termodifikasi asam askorbat lebih baik dibandingkan kitosan tanpa modifikasi. Konsentrasi asam askorbat optimum adalah pada konsentrasi $40 \mathrm{mmol} / \mathrm{L}$ dan mampu mengawetkan daging ayam hingga 4 minggu.

\section{Pendahuluan}

Daging ayam merupakan salah satu makanan yang paling banyak dikonsumsi oleh masyarakat yang pada umumnya merupakan daging ayam karkas. Karkas adalah bagian tubuh ayam setelah dilakukan penyembelihan secara halal, pencabutan bulu dan pengeluaran jeroan, tanpa kepala, leher, kaki, paruparu, dan atau ginjal (SNI, 2009). Daging ayam merupakan bahan pangan yang mudah busuk, untuk memperpanjang daya simpan atau membuat daging ayam segar lebih awet dalam penyimpanannya 
seringkali ditemukan adanya bahan tambahan makanan seperti bahan pengawet yang berbahaya [1]. Untuk itu diperlukan bahan pengawet alternatif yang alami dan tidak berbahaya untuk dikonsumsi seperti kitosan [2].

Kitosan adalah kitin yang telah mengalami proses penghilangan gugus asetil (deasetilasi) dengan penambahan alkali [3]. Kitosan merupakan polisakarida kationik biodegradable yang memiliki aktivitas antimikroba yang baik. Oleh karena itu kitosan sangat cocok diformulasikan sebagai lapisan pada makanan yang telah terbukti efektif dalam memperpanjang usia (shelf life) [4]. Pada prinsipnya kitosan mengandung gugus amino bebas bermuatan positif dalam suasana asam yang dapat mengikat muatan negatif dari mikrobia [5]. Adanya gugus amino dan hidroksil pada kitosan menyebabkan kitosan mudah dimodifikasi secara kimia menghasilkan derivat-derivat kitosan. Modifikasi dapat dilakukan secara fisik dan kimia dan diharapkan dapat meningkatkan kinerja kitosan dan dapat mempertahankan kestabilannya dalam [6]. Kitosan dimodifikasi dengan asam askorbat karena asam askorbat merupakan bahan kimia yang tidak beracun, lebih ekonomis dan mudah didapat, diharapkan mampu menambah gugus aktif pada kitosan sehingga memperkuat fisik dan mampu meningkatkan kemampuan kitosan dalam aplikasinya sebagai zat antimikroba atau sebagai pengawet bahan pangan.

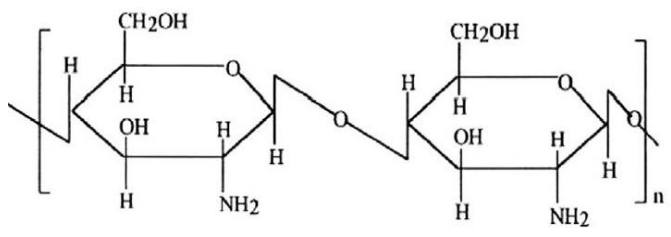

Gambar 1. Struktur molekul kitosan

Kitosan sudah banyak diaplikasikan sebagai pengawet bahan pangan. Kitosan diaplikasikan sebagai zat antimikroba pada ikan nila dan dilaporkan mampu memperpanjang umur simpan ikan nila pada suhu ruang hingga empat hari [7]. Kitosan juga sudah dipublikasikan dapat memperpanjang usia daging ayam mentah siap konsumsi yang disebabkan oleh adanya lapisan kitosan dapat menyebabkan retensi yang baik dalam memperpanjang umur simpan daging ayam dalam suhu dingin, secara signifikan mampu mengurangi pertumbuhan bakteri B. Cereus, E. Coli, dan P. Fluorescens [8]. Modifikasi kitosan dengan asam askorbat sebagai bahan pengawet telah dilaporkan dapat memperpanjang umur pascapanen buah lengkeng dengan pengaturan suhu dan kelembaban ruang penyimpanan dengan metode coating, dengan digunakan kitosan dengan konsentrasi $1 \%$ dan asam askorbat $40 \mathrm{mmol} / \mathrm{L}$ [9].

Berdasarkan latar belakang di atas maka peneliti telah memanfaatkan kitosan temodifikasi asam askorbat dengan variasi konsentrasi dan mengaplikasikannya sebagai pengawet pada daging ayam. Untuk menguji hal tersebut dilakukan pengujian secara organoleptik (bau, warna, dan kenampakan fisik) dan uji mikrobiologi terhadap Angka Lempeng Total (ALT). Menurut SNI 3924:2009 tentang Mutu Karkas dan Daging Ayam, syarat mutu biologis daging ayam adalah dengan jumlah Total Plat Count (TPC) atau Angka Lempeng Total (ALT) maximum $1 \times 10^{6} \mathrm{koloni} / \mathrm{g}$.

Pengembangan penelitian ini dilakukan dengan melakukan modifikasi kitosan dengan asam askorbat dengan konsentrasi asam askorbat yang divariasikan sehingga diharapkan diperoleh kitosan termodifikasi asam askorbat dengan kemampuan yang lebih baik dalam aplikasinya sebagai pengawet daging ayam. Variasi konsentrai asam askorbat dilakukan dengan tujuan agar diperoleh konsentrasi asam askorbat yang paling optimum. Kitosan termodifikasi asam askorbat dianalisis menggunakan spektrofotometer FTIR.

\section{Metode Penelitian}

\section{Alat dan Bahan}

Alat: Alat yang digunakan pada penelitian ini terdiri atas alat-alat gelas, Autoklaf klinis, Hotplate thermo scientific, Inkubator, Magnetic stirer, Neraca analitik OHAUS, Laminair flow, pH meter, Fourier Transform Infrared (FTIR) Simadzu, dan Colony counter. Bahan: Bahan-bahan yang digunakan dalam penelitian ini terdiri atas sampel kitosan produksi IPB, $\mathrm{CH}_{3} \mathrm{COOH}$ (merck) Alkohol (Pro Analis, Merck), Asam askorbat (Pro Analis, Merck), Natrium hidroksida (Pro Analis, Merck), Buffered peptone water (BPW) (Pro Analis, Merck), NA (Nutrient Agar) (Pro Analis, Merck), Kitosan (IPB), Aquades, dan Daging ayam karkas broiler.

\section{Re-deasetilasi Kitosan}

Kitosan yang diperoleh dari IPB sebanyak 40 gram diredeasetilasi dengan penambahan $\mathrm{NaOH} 50 \%$ sebanyak 1:5 dan dilakukan pemanasan dan pengadukan menggunakan Hotplate Thermo Scientific pada suhu $85^{\circ}$ $90^{\circ} \mathrm{C}$ selama 4 jam. Selanjutnya dilakukan penetralan dengan aquadest sampai $\mathrm{pH} \quad 7$ dan dilakukan pengeringan. Kitosan yang telah diredeasetilasi maupun yang belum diredeasetilasi diuji menggunakan Spektrofotometer FTIR untuk mengetahui prosentase derajat deasetilasi.

\section{Pembuatan Larutan Kitosan}

Kitosan setelah diredeasetilasi dilarutkan dalam asam asetat glasial $1 \%$ dengan konsentrasi $1 \%$. Pengadukan dilakukan selama 1 jam sampai homogen.

\section{Pembuatan Larutan Kitosan Termodifikasi Asam} Askorbat

Kitosan setelah diredeasetilasi dilarutkan dalam asam asetat $1 \%$ dengan konsentrasi kitosan sebanyak $1 \%$. Sedikit demi sedikit dilakukan penambahan asam askorbat dengan sebanyak $20 \mathrm{mmol} / \mathrm{L}, 30 \mathrm{mmol} / \mathrm{L}$, dan $40 \mathrm{mmol} / \mathrm{L}$ kemudian dilarutkan sampai homogen dengan waktu pengadukan masing-masing selama 1 jam. Kitosan yang telah dimodifikasi dengan asam askorbat diuji menggunakan Spektrofotometer FTIR.

\section{Preparasi dan Perlakuan Sampel}

Daging ayam karkas broiler yang diperoleh di supermarket dengan ukuran yang seragam dibagi menjadi tiga kelompok, kelompok pertama (A) 
dilakukan perlakuan dengan air sebagai control. Kelompok kedua (B) dilakukan perlakuan dengan kitosan $1 \%$ dalam asam asetat $2 \%$. Kelompok ketiga (C) dilakukan perlakuan dengan termodifikasi asam askorbat $20 \mathrm{mmol} / \mathrm{L}$ dengan konsentrasi 1\%, Kelompok keempat (D) dilakukan perlakuan dengan termodifikasi asam askorbat $30 \mathrm{mmol} / \mathrm{L}$ dengan konsentrasi kitosan $1 \%$, dan Kelompok ketiga (C) dilakukan perlakuan dengan termodifikasi asam askorbat $40 \mathrm{mmol} / \mathrm{L}$ dengan konsentrasi kitosan 1\%, masing-masing dilakukan perendaman selama 10 menit. Setelah kering dilakukan penyimpanan dalam kantung polyethylene dan disimpan dalam suhu ruang dingin $3-5^{\circ} \mathrm{C}$.

\section{Hasil dan Pembahasan}

\section{Re-deasetilasi Kitosan dan Penentuan Derajat Deasetilasi}

Redeasetilasi adalah proses deasetilasi kembali yang merupakan pengurangan gugus asetil pada ($\mathrm{COCH}_{3}$ ) dalam kitin yang akan digantikan oleh atom hidrogen sehingga gugus $-\mathrm{NHCOCH}_{3}$ berubah menjadi amina $-\mathrm{NH}_{2}$ Prinsipnya adalah hidrolisis amida dalam larutan basa yang meliputi dua tahapan yaitu adisi $\mathrm{OH}-$ dan eliminasi yang disertai serah terima proton. Salah satu parameter penting dari kitosan yang mempengaruhi sifat kitosan adalah derajat deasetilasi (DD). Dengan proses redeasetilasi ini diharapkan akan diperoleh kitosan dengan DD yang tinggi. Hasil dari proses ini diuji menggunakan spektrofotometer FTIR untuk memperoleh data spektra puncak yang dihasilkan. Penentuan derajat deasetilasi kitosan dihitung dengan metode Base Line oleh Domszy dan Robert [10].

Bahan awal berupa kitosan yang diperoleh dari IPB sebelumnya telah melalui proses deasetilasi tetapi belum diketahui derajat deasetilasinya. Analisis FTIR dilakukan sebelum redeasetilasi untuk mengetahui derajat deasetilasinya. Berikut spektra FTIR kitosan sebelum redeasetilasi ditunjukkan pada gambar 1.

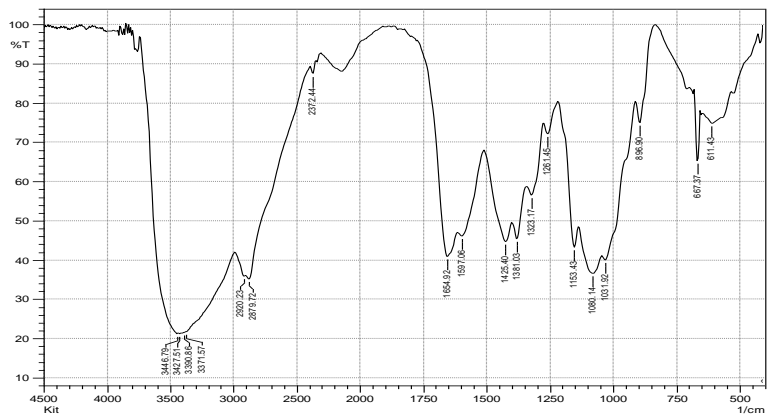

Gambar 2. Spektra FTIR Kitosan Sebelum Redeasetilasi

Tabel 1: Bilangan Gelombang dan Prediksi Gugus yang terdapat pada Kitosan Sebelum Redeasetilasi

\begin{tabular}{cc}
\hline $\begin{array}{c}\text { Bilangan Gelombang } \\
\left(\mathrm{cm}^{-1}\right)\end{array}$ & Prediksi Gugus \\
\hline 3446.79 & Uluran N-H tumpang tindih \\
O-H \\
2920.23 dan 2879.72 & Uluran C-H
\end{tabular}

1654.92 dan 1597.06

1080.14
Uluran $\mathrm{C}=\mathrm{O}$ dan tekuk

Uluran C-N amida sekunder

Gambar 2 dan tabel 1 menunjukkan bahwa kitosan yang diperoleh sebelum diredeasetilasi memiliki puncak pada $3446.79 \mathrm{~cm}^{-1}$ yang mengindikasikan adanya uluran $\mathrm{N}-\mathrm{H}$ dengan transmitansi $21,33 \%$, gugus $\mathrm{C}-\mathrm{H}$ ditunjukkan pada $2920.23 \mathrm{~cm}^{-1}$ dengan transmitansi $35,97 \%$, gugus karbonil $(\mathrm{C}=0)$ ditunjukkan pada 1654.92 $\mathrm{cm}^{-1}$ dengan transmitansi $40,94 \%$ dan gugus $\mathrm{C}-\mathrm{N}$ ditunjukkan pada $1080.14 \mathrm{~cm}^{-1}$ dengan transmitansi $36,67 \%$.

Berdasarkan perhitungan dengan metode base line, diperoleh derajat deasetilasi sebesar 65,71\%. Perhitungan untuk menentukan derajat deasetilasi dapat dilihat pada lampiran 3. Derajat deasetilasi kitosan sebelum diredeasetilasi tersebut menunjukkan adanya gugus $\mathrm{NH}_{2}$ sebesar $65,71 \%$ dan gugus asetil yang masih tersisa pada kitosan adalah sebesar $34,29 \%$. Analisis FTIR juga dilakukan setelah proses redeasetilasi dengan tujuan untuk mengetahui kenaikan jumlah derajat deasetilasi kitosan. Hasil analisis menunjukkan perbedaan yang cukup signifikan antara kitosan sebelum dan sesudah dilakukan proses redeasetilasi. Spektra FTIR kitosan setelah diredeasetilasi ditunjukkan oleh gambar 2.

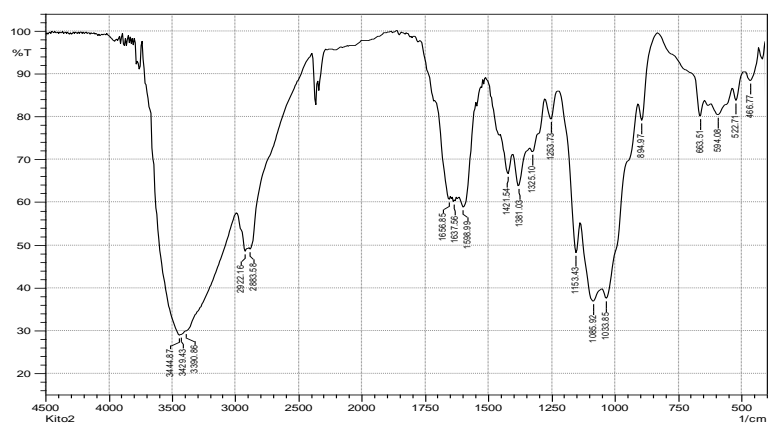

Gambar 3. Spektra FTIR Kitosan Setelah Redeasetilasi

Tabel 2: Bilangan Gelombang dan Prediksi Gugus yang terdapat pada Kitosan Setelah Redeasetilasi

\begin{tabular}{cc}
\hline $\begin{array}{c}\text { Bilangan Gelombang } \\
\left(\mathrm{cm}^{-1}\right)\end{array}$ & Prediksi Gugus \\
\hline 3729,43 & Uluran N-H tumpang tindih \\
O-H \\
2922,16 dan 2883,58 & Uluran C-H \\
1656,85 & Uluran C=O dan tekuk \\
1085.52 & amida sekunder \\
Uluran C-N
\end{tabular}

Gambar 3 dan tabel 2 menunjukkan bahwa kitosan yang diperoleh setelah diredeasetilasi memiliki puncak pada $3729.43 \mathrm{~cm}^{-1}$ yang mengindikasikan adanya uluran $\mathrm{N}-\mathrm{H}$ dengan transmitansi $29,13 \%$ gugus $\mathrm{C}-\mathrm{H}$ pada $2922.16 \mathrm{~cm}^{-1}$ dengan transmitansi $48,45 \%$, gugus karbonil $(\mathrm{C}=\mathrm{O})$ ditunjukkan pada $1656.85 \mathrm{~cm}^{-1}$ dengan transmitansi $58,97 \%$ dan gugus $\mathrm{C}-\mathrm{N}$ pada $1085.52 \mathrm{~cm}^{-1}$ dengan transmitansi $36,12 \%$. Berdasarkan perhitungan, diperoleh derajat deasetilasi sebesar 72,89\%. Perhitungan untuk menentukan derajat deasetilasi 
dapat dilihat pada lampiran 4. Derajat deasetilasi kitosan setelah diredeasetilasi tersebut menunjukkan adanya gugus $\mathrm{NH}_{2}$ sebesar $72,89 \%$ dan gugus asetil yang masih tersisa pada kitosan adalah sebesar $27,11 \%$. Dari kedua hasil analisis FTIR tersebut, derajat deasetilasi kitosan meningkat $7,18 \%$. Proses redeasetilasi dapat meningkatkan nilai DD dan menurunkan nilai $\mathrm{BM}$ kitosan yang diperoleh. Semakin tinggi derajat deasetilasi kitosan, maka gugus asetil yang terdapat dalam kitosan semakin sedikit dan gugus $\mathrm{NH}_{2}$ semakin banyak sehingga kitosan semakin mudah larut dalam asam asetat. Reaksi yang terjadi pada proses deasetilasi ditunjukan pada gambar 4 .
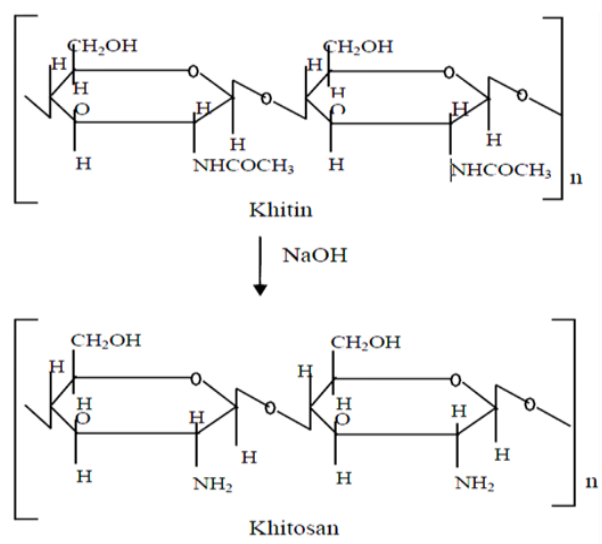

Gambar 4. Reaksi Deasetilasi Kitosan

Proses deasetilasi (penghilangan gugus asetil) berlangsung dalam kondisi basa karena gugus $\mathrm{N}$-asetil tidak dapat dihilangkan dengan reagensia asam tanpa hidrolisis polisakaridanya. Mula-mula terjadi reaksi adisi, dimana gugus $\mathrm{OH}^{-}$masuk ke dalam gugus $\mathrm{NHCOCH}_{3}$ kemudian terjadi eliminasi gugus $\mathrm{CH}_{3} \mathrm{COO}^{-}$ sehingga dihasilkan suatu amida. Di bawah kondisi basa yang kuat, gugus asetat yang berdekatan dengan gugus hidroksil cis dapat mengalami $\mathrm{N}$-deasetilasi, tetapi gugus yang trans lebih resistansi. Konsentrasi $\mathrm{NaOH}$ yang semakin tinggi, menyumbangkan gugus - $\mathrm{OH}$ yang semakin banyak, sehingga gugus $\mathrm{CH}_{3} \mathrm{COO}^{-}$yang tereliminasi juga semakin banyak dan menghasilkan gugus amida yang semakin banyak pula [7].

\section{Kitosan Termodifikasi Asam Askorbat}

Pembuatan kitosan termodifikasi asam askorbat dilakukan dengan tujuan untuk menginteraksikan kitosan dan asam askorbat. Asam askorbat merupakan salah satu senyawa antioksidan, sifat antioksidan tersebut mampu memperlambat atau menetralkan oksigen yang digunakan dalam perkembangbiakan mikroorganisme pada bahan pangan [11]. Hasil dianalisis menggunakan spektrofotometer FTIR untuk mengetahui gugus-gugus yang berinteraksi. Hasil spektra FTIR ditunjukkan oleh gambar 5 .

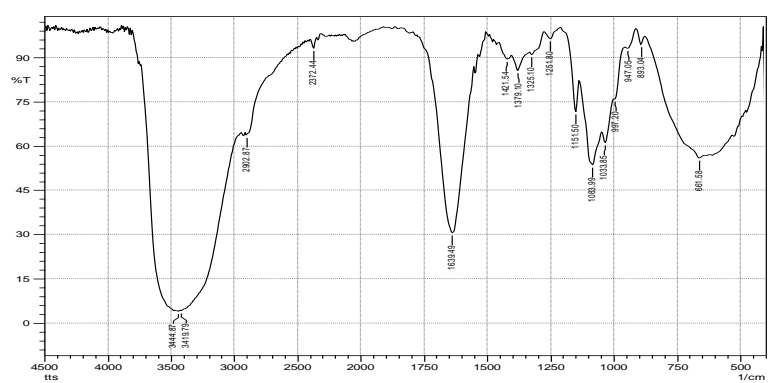

Gambar 5. Spektra FTIR Kitosan termodifikasi asam askorbat

Tabel 3: Bilangan Gelombang dan Prediksi Gugus yang terdapat pada Kitosan Termodifikasi Asam Askorbat

\begin{tabular}{cc}
\hline $\begin{array}{c}\text { Bilangan Gelombang } \\
\left(\mathrm{cm}^{-1}\right)\end{array}$ & Prediksi Gugus \\
\hline 3444.87 & Uluran N-H tumpang tindih \\
2902.87 & O-H \\
1639.49 & Uluran C-H \\
1083.99 & $\begin{array}{c}\text { Uluran C=O dan tekuk } \\
\text { amida sekunder }\end{array}$ \\
\hline
\end{tabular}

Gambar 5 dan tabel 3 menunjukkan bahwa kitosan termodifikasi asam askorbat yang diperoleh memiliki puncak pada $3444.87 \mathrm{~cm}^{-1}$ yang mengindikasikan adanya uluran $\mathrm{N}-\mathrm{H}$ dengan transmitansi $4,01 \%$ dan gugus karbonil (C=O) ditunjukkan pada $2902.87 \mathrm{~cm}^{-1}$ dengan transmitansi $63,87 \%$. Terjadi penurunan prosentase transmitansi pada gugus $\mathrm{O}-\mathrm{H}, \mathrm{C}=\mathrm{O}$, dan $\mathrm{C}-\mathrm{H}$ yang menunjukkan adanya interaksi antara kitosan dan asam askorbat. Transmitansi berbanding terbalik pada konsentrasi, semakin tinggi transmitansi maka konsentrasi suatu gugus pada suatu senyawa semakin berkurang. Mekanisme yang mungkin terjadi antara kitosan dan asam askorbat adalah sebagai berikut:

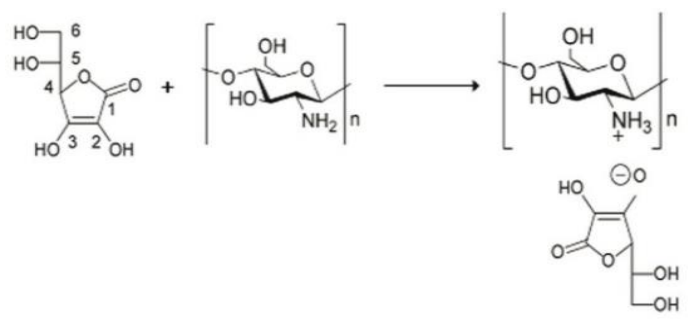

Gambar 6. Mekanisme Reaksi Kitosan dan Asam Askorbat

Asam askorbat menyediakan proton bagi kitosan dan menunjukkan beberapa gugus elektrofilik dalam interaksi antara kitosan dan asam askorbat [12].

Penentuan Umur Simpan Daging Ayam oleh Aplikasi Kitosan Termodifikasi Asam Askorbat Sebagai Antimikroba

Penentuan umur simpan daging ayam oleh aplikasi kitosan termodifikasi asam askorbat dilakukan dengan tujuan untuk mengetahui efektivitas kitosan termodifikasi asam askorbat dalam aplikasinya sebagai pengawet daging ayam. Metode yang digunakan dalam proses pengawetan adalah metode coating yang dengan 
pencelupan pada permukaan daging ayam. Hasil aplikasi diuji dengan metode pengujian yang dilakukan adalah metode penentuan Angka Lempeng Total (ALT) atau TPC (Total Plate Count) untuk menunjukkan jumlah mikroba yang terdapat dalam suatu produk dengan cara menghitung koloni bakeri yang ditumbuhkan melalui media agar. Metode pengujian Angka Lempeng Total dilakukan sesuai dengan SNI 2897:2008 tentang Metode Pengujian Cemaran Mikroba dalam Daging, Telur, dan Susu serta Hasil Olahannya. Menurut SNI 3924:2009 tentang Mutu Karkas dan Daging Ayam memiliki persyaratan maksimum mutu mikrobiologi pada parameter Angka Lempeng Total maksimum $1 \times 10^{6}$ cfu/g. Prinsip dari metode hitungan cawan adalah jika sel jasad renik yang masih hidup ditumbuhkan pada medium agar, maka sel jasad renik tersebut akan berkembang biak dan membentuk koloni yang dapat dilihat langsung dan dihitung dengan mata tanpa menggunakan mikroskop.

Dilakukan optimasi konsentrasi asam askorbat yang ditambahkan pada kitosan untuk mencari konsentrasi asam askorbat optimum sebagai antimikroba pada daging ayam. Variasi konsentrasi asam askorbat yang dilakukan yaitu $20 \mathrm{mmol} / \mathrm{L}, 30$ $\mathrm{mmol} / \mathrm{L}$, dan $40 \mathrm{mmol} / \mathrm{L}$. Hasil penelitian jumlah total mikroba pada daging ayam dengan perbandingan kitosan dan kitosan termodifikasi asam askorbat yang dilakukan variasi konsentrasinya dapat dilihat pada grafik berikut.

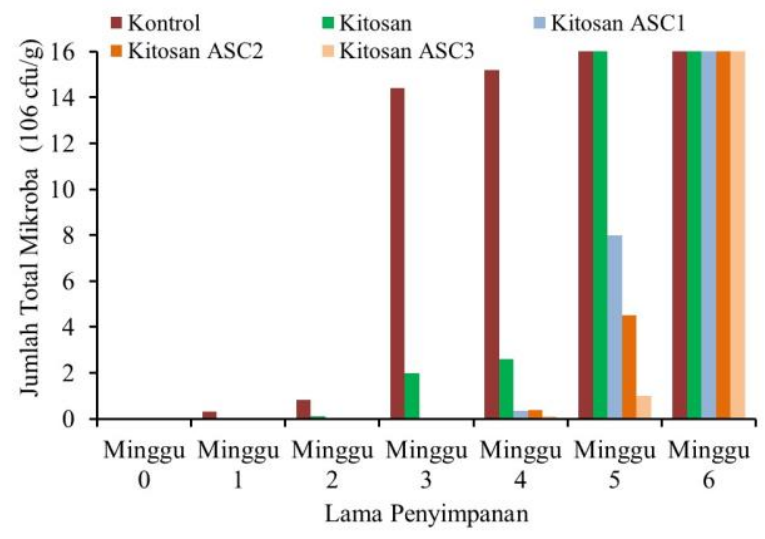

Gambar 7. Hubungan lama penyimpanan terhadap jumlah mikroba

Gambar 7 menunjukkan perbandingan jumlah total mikroba pada kontrol, kitosan $1 \%$, kitosan termodifikasi asam askorbat 20mmol/L (kitosan ASC1), kitosan termodifikasi asam askorbat $30 \mathrm{mmol} / \mathrm{L}$ (kitosan ASC2), dan kitosan termodifikasi asam askorbat $40 \mathrm{mmol} / \mathrm{L}$ (kitosan ASC3). Data total mikroba dapat dilihat pada lampiran IV. Dari grafik tersebut, jumlah total mikroba kontrol pada minggu ke 3, penambahan kitosan pada minggu ke 4, dan penambahan kitosan termodifikasi asam askorbat $20 \mathrm{mmol} / \mathrm{L}$ pada minggu ke 4 sudah tidak layak untuk dikonsumsi dikarenakan sudah berada diatas ambang batas yang ditetapkan oleh SNI maximum 1 x $10^{6} \mathrm{koloni} / \mathrm{g}$. Pada sampel dengan perlakuan penambahan kitosan termodifikasi asam askorbat $30 \mathrm{mmol} / \mathrm{L}$ dan $40 \mathrm{mmol} / \mathrm{L}$ sampai minggu ke
5 masih layak untuk dikonsumsi dikarenakan masih berada dibawah ambang batas cemaran mikroba yang ditetapkan oleh SNI. Seluruh sampel daging ayam pada minggu ke 6 sudah tidak layak untuk dikonsumsi dan melebihi ambang batas total mikroba yang ditetapkan oleh SNI.

Kitosan mengandung gugus amino bebas yang bermuatan positif, yang dapat mengikat muatan negatif dari dinding sel mikrobia [5]. Adanya interaksi ini diperkirakan akan mengakibatkan dinding sel tidak mampu mengatur pertukaran zat-zat dari dan kedalam sel, kemudian membran sel mengalami lisis sehingga aktifitas metabolisme akan terhambat dan pada akhirnya mikroba akan mengalami kematian [13]. Pada umumnya keefektifan kerja antimikroba berhubungan secara eksponensial dengan konsentrasi [14]. Mekanisme kerja zat antimikroba secara umum adalah dengan merusak struktur-struktur utama dari sel mikroba seperti dinding sel, sitoplasma, ribosom, dan membran sitoplasma. Dengan adanya zat antimikroba (dalam hal ini adalah larutan kitosan dan larutan kitosan termodifikasi asam askorbat yang bersifat asam) akan menyebabkan denaturasi protein. Keadaan ini menyebabkan inaktivasi enzim, sehingga sistem metabolisme terganggu atau menjadi rusak dan akhirnya tidak ada aktivitas sel mikroba [11]. Sifat tersebut menjadikan kitosan dapat menghambat pertumbuhan mikroba pada daging ayam dan dapat dimanfaatkan sebagai antimikroba. Kemampuan kitosan sebagai antimikroba diperkuat dengan adanya modifikasi dengan asam askorbat. Interaksi kitosan dengan asam askorbat yang mengakibatkan kinerja antimikroba yang lebih baik sehingga mampu membuat daging ayam lebih awet.

Metode hitungan cawan merupakan cara yang paling sensitif untuk menentukan jumlah jasad renik karena hanya sel yang masih hidup yang dihitung, beberapa jenis jasad renik dapat dihitung sekaligus, dan dapat digunakan untuk isolasi dan identifikasi jasad renik karena koloni yang terbentuk mungkin berasal dari suatu jasad renik yang mempunyai penampakan pertumbuhan spesifik [15]. Secara umum analisis Angka Lempeng Total sudah cukup mewakili parameter lain batas total mikroba maksimum yang disajikan dalam SNI 3924:2009 seperti pada parameter Staphylococcus aureus, Salmonella sp, Escherichia coli, Campylobacter sp dan Angka Paling Mungkin (APM) Coliform secara kualitatif karena pada prinsipnya analisis dengan metode hitungan cawan ini adalah jika sel jasad renik yang masih hidup ditumbuhkan pada media agar, maka sel jasad renik tersebut akan berkembang biak dan membentuk koloni yang dapat dilihat langsung dan dihitung dengan mata tanpa menggunakan mikroskop dan metode ini merupakan cara yang paling sensitif untuk menentukan jumlah jasad renik suatu bahan makanan [15]. Teknik yang digunakan untuk menumbuhkan mikroorganisme pada media agar memungkinkannya tumbuh dengan agak berjauhan dari sesamanya, juga memungkinkan setiap selnya berhimpun membentuk koloni. Semua sel dalam koloni itu sama, dianggap kesemuanya itu merupakan 
keturunan (progeni) satu mikroorganisme dan karena itu mewakili apa yang disebut mikrobiologiwan biakan murni [16]. TBUD (Terlalu Banyak Untuk Dihitung) menunjukkan bahwa jumlah koloni yang terhitung lebih dari 300 koloni. Hasil hitungan cawan yang baik adalah yang mengandung koloni $<300$ koloni.

Daging ayam disimpan pada suhu dingin karena pada dasarnya pendinginan dapat memperlambat reaksi-reaksi metabolisme, dimana pada umunya setiap penurunan suhu $8^{\circ} \mathrm{C}$ kecepatan reaksi akan berkurang menjadi kira-kira setengahnya. Pendinginan tidak dapat membunuh mikroba tetapi hanya menghambat pertumbuhannya [17]. Selain dilakukan pengujian jumlah total mikroba, dilakukan pula pengamatan secara organoleptik terhadap bau, warna, dan kenampakan fisik.

Keadaan fisik daging ayam karkas broiler secara organoleptik tanpa penambahan kitosan mengalami penurunan yang signifikan dikarenakan tidak adanya penambahan senyawa antimikroba yang dapat menekan pertumbuhan bakteri sehingga mikroba mulai tumbuh dan lama kelamaan daging mulai mengalami pembusukan. Lain halnya dengan kondisi daging yang diperlakukan dengan penambahan kitosan dan kitosan termodifikasi asam askorbat.

Dapat diketahui pula pada daging kontrol pada minggu ke tiga dan pada daging dengan penambahan kitosan pada minggu ke empat mulai mengalami gejala pembusukan yang ditandai dengan timbulnya bau busuk. Bau busuk dibentuk terutama oleh organisme anaerob dengan jalan dekomposisi protein dan asam amino dan bau asam dengan jalan dekomposisi gulagula dan molekul-molekul kecil lainnya [18]. Seperti yang telah dijelaskan sebelumnya, kitosan dan kitosan termodifikasi asam askorbat mampu menekan pertumbuhan mikroorganisme dan membuat daging ayam lebih awet. Kitosan mampu menekan pertumbuhan bakteri sampai minggu ke empat dan kitosan termodifikasi asam askorbat dengan konsentrasi paling optimum pada konsentrasi asam askorbat $40 \mathrm{mmol} / \mathrm{L}$ yang mampu menekan pertumbuhan mikroba hingga minggu ke empat.

\section{Kesimpulan}

Kitosan berhasil diredeasetilasi dan mampu meningkatkan derajat deasetilasi kitosan sebesar 7,18\% yang ditunjukkan oleh spektra FTIR. Kitosan termodifikasi asam askorbat berhasil digunakan sebagai pengawet pada daging ayam karkas broiler. Konsentrasi asam askorbat paling optimum digunakan untuk modifikasi adalah pada konsentrasi $40 \mathrm{mmol} / \mathrm{L}$ dan mampu mengawetkan daging ayam hingga 4 minggu.

\section{Daftar Pustaka}

[1] Sweetie R. Kanatt, Ramesh Chander, Arun Sharma, Chitosan and mint mixture: A new preservative for meat and meat products, Food Chemistry, 107, 2, (2008)

$845-852$ http://dx.doi.org/10.1016/j.foodchem.2007.08.088
[2] Abdel E Ghaly, D Dave, S Budge, MS Brooks, Fish spoilage mechanisms and preservation techniques, American Journal of Applied Sciences, 7, 7, (2010) 859

[3] Mike TL Tobing, Nor Basid Adibawa Prasetya, Khabibi Khabibi, Peningkatan Derajat Deasetilasi Kitosan dari Cangkang Rajungan dengan Variasi Konsentrasi $\mathrm{NaOH}$ dan Lama Perendaman, Jurnal Kimia Sains dan Aplikasi, 14, 3, (2011) 83-88

[4] Maria Vargas, Amparo Chiralt, Ana Albors, Chelo González-Martínez, Effect of chitosan-based edible coatings applied by vacuum impregnation on quality preservation of fresh-cut carrot, Postharvest Biology and Technology, 51, 2, (2009) 263-271 http://dx.doi.org/10.1016/j.postharvbio.2008.07.019

[5] Agus Widodo, Prasetyo A Mardiah, Potensi Kitosan dari Sisa Udang Sebagai Koagulan Logam Berat Industri Tekstil, Surabaya: Jurusan Teknik Kimia, Institut Teknologi Sepuluh Nopember, (2005)

[6] CB Li, S Hein, K Wang, Biosorption of chitin and chitosan, Materials Science and Technology, 24, 9, (2008) http://dx.doi.org/10.1179/174328408X341771

[7] Kaviani Suciana Alifah, M Si Khabibi, Didik Setiyo Widodo, M Si, Pemanfaatan Kitosan Dari Limbah Kulit Udang Windu (Penaeus Monodon) Sebagai Bahan Antimikroba Pada Proses Penyimpanan Ikan Nila (Oreochromis Niloticus), Chem Info Journal, 1, 2, (2013) 1-9

[8] Sweetie R. Kanatt, M. S. Rao, S. P. Chawla, Arun Sharma, Effects of chitosan coating on shelf-life of ready-to-cook meat products during chilled storage, LWT - Food Science and Technology, 53, 1, (2013) http://dx.doi.org/10.1016/j.lwt.2013.01.019

[9] Dequan Sun, Guobin Liang, Jianghui Xie, Xintao Lei, Yiwei Mo, Improved preservation effects of litchi fruit by combining chitosan coating with ascorbic acid treatment during postharvest storage, African Journal of Biotechnology, 9, 22, (2010) 3272-3279

[10] Serkan Keleşoğlu, Comparative adsorption studies of heavy metal ions on chitin and chitosan biopolymers, İzmir Institute of Technology,

[11] Wesley A. Volk, Margaret F. Wheeler, Mikrobiologi Dasar, Markham, Erlangga, Jakarta, 1993.

[12] Po-Hui Chen, Ya-Hsi Hwang, Ting-Yun Kuo, FangHsuan Liu, Juin-Yih Lai, Hsyue-Jen Hsieh, Improvement in the properties of chitosan membranes using natural organic acid solutions as solvents for chitosan dissolution, Journal of Medical and Biological Engineering, 27, 1, (2007) 23-28

[13] JT Murtini, Yusma Dwiyitno, Penurunan kandungan kolesterol pada cumicumi dengan kitosan larut asam dan pengepresan, Prosiding Seminar Nasional Tahunan V Hasil Kelautan, (2008).

[14] Koes Irianto, Mikrobiologi Menguak Dunia Mikroorganisme, Edisi I. Yrama Widya, Bandung, (2006)

[15] S Fardiaz, Mikrobiologi Pangan, Gramedia Pustaka Utama, Jakarta, 1992.

[16] MJ Pelczar, ECS Chan, Dasar-Dasar Mikrobiologi, R. Hadioetomo, T. Imas, S. Tjitrosomo, S. Angka, Universitas Indonesia Press, Jakarta, 1986. 
[17] F. G. Winarno, Kimia Pangan dan Gizi, Penerbit Gramedia, Jakarta, 1992.

[18] RA Lawrie, Ilmu Daging, A. Parakkasi, Penerbit UI Press, Jakarta, Indonesia, 2003. 